\title{
Ethical Issues in Cancer Patient Care
}




\section{Cancer Treatment and Research}

\section{Steven T. Rosen, M.D., Series Editor}

Sugarbaker, P.H. (ed): Management of Gastric Cancer. 1991. ISBN 0-7923-1102-7.

Pinedo H.M., Verweij J., Suit, H.D., (eds): Soft Tissue Sarcomas: New Developments in the Multidisciplinary Approach to Treatment. 1991. ISBN 0-7923-1139-6.

Ozols, R.F., (ed): Molecular and Clinical Advances in Anticancer Drug Resistance. 1991. ISBN 0-7923-1212-0.

Muggia, F.M. (ed): New Drugs, Concepts and Results in Cancer Chemotherapy 1991. ISBN 0-7923-1253-8.

Dickson, R.B., Lippman, M.E. (eds): Genes, Oncogenes and Hormones: Advances in Cellular and Molecular Biology of Breast Cancer. 1992. ISBN 0-7923-1748-3.

Humphrey, G. Bennett, Schraffordt Koops, H., Molenaar, W.M., Postma, A., (eds): Osteosarcoma in Adolescents and Young Adults: New Developments and Controversies. 1993. ISBN 0-7923-1905-2.

Benz, C. C., Liu, E. T. (eds): Oncogenes and Tumor Suppressor Genes in Human Malignancies. 1993. ISBN 0-7923-1960-5.

Freireich, E.J., Kantarjian, H., (eds): Leukemia: Advances in Research and Treatment. 1993. ISBN 0-7923-1967-2.

Dana, B. W., (ed): Malignant Lymphomas. Including Hodgkin's Disease: Diagnosis, Management, and Special Problems. 1993. ISBN 0-7923-2171-5.

Nathanson, L. (ed): Current Research and Clinical Management of Melanoma. 1993. ISBN 0-7923-2152-9.

Verweij, J., Pinedo, H. M., Suit, H. D. (eds): Multidisciplinary Treatment of Soft Tissue Sarcomas. 1993. ISBN 0-7923-2183-9.

Rosen, S. T., Kuzel, T. M. (eds): Immunoconjugate Therapy of Hematologic Malignancies. 1993. ISBN 0-7923-2270-3.

Sugarbaker, P. H. (ed): Hepatobiliary Cancer. 1994. ISBN 0-7923-2501-X.

Rothenberg, M. L. (ed): Gynecologic Oncology: Controversies and New Developments. 1994. ISBN 0-7923-2634-2.

Dickson, R. B., Lippman, M. E. (eds.): Mammary Tumorigenesis and Malignant Progression. 1994. ISBN 0-7923-2647-4.

Hansen, H. H., (ed): Lung Cancer. Advances in Basic and Clinical Research. 1994. ISBN 0-7923-2835-3.

Goldstein, L.J., Ozols, R. F. (eds.): Anticancer Drug Resistance. Advances in Molecular and Clinical Research. 1994. ISBN 0-7923-2836-1.

Hong, W.K., Weber, R.S. (eds.): Head and Neck Cancer. Basic and Clinical Aspects. 1994. ISBN 0-7923-3015-3.

Thall, P.F. (ed): Recent Advances in Clinical Trial Design and Analysis. 1995. ISBN 0-7923-3235-0.

Buckner, C. D. (ed): Technical and Biological Components of Marrow Transplantation. 1995. ISBN 0-7923-3394-2.

Winter, J.N. (ed.): Blood Stem Cell Transplantation. 1997. ISBN 0-7923-4260-7.

Muggia, F.M. (ed): Concepts, Mechanisms, and New Targets for Chemotherapy. 1995. ISBN 0-7923-3525-2.

Klastersky, J. (ed): Infectious Complications of Cancer. 1995. ISBN 0-7923-3598-8.

Kurzrock, R., Talpaz, M. (eds): Cytokines: Interleukins and Their Receptors. 1995. ISBN 0-7923-3636-4.

Sugarbaker, P. (ed): Peritoneal Carcinomatosis: Drugs and Diseases. 1995. ISBN 0-7923-3726-3.

Sugarbaker, P. (ed): Peritoneal Carcinomatosis: Principles of Management. 1995. ISBN 0-7923-3727-1.

Dickson, R.B., Lippman, M.E. (eds.): Mammary Tumor Cell Cycle, Differentiation and Metastasis. 1995. ISBN 0-7923-3905-3.

Freireich, E.J, Kantarjian, H. (eds.): Molecular Genetics and Therapy of Leukemia. 1995. ISBN 0-7923-3912-6.

Cabanillas, F., Rodriguez, M.A. (eds.): Advances in Lymphoma Research. 1996. ISBN 0-7923-3929-0.

Miller, A.B. (ed.): Advances in Cancer Screening. 1996. ISBN 0-7923-4019-1.

Hait, W.N. (ed.): Drug Resistance. 1996. ISBN 0-7923-4022-1.

Pienta, K.J. (ed.): Diagnosis and Treatment of Genitourinary Malignancies. 1996. ISBN 0-7923-4164-3.

Arnold, A.J. (ed.): Endocrine Neoplasms. 1997. ISBN 0-7923-4354-9.

Pollock, R.E. (ed.): Surgical Oncology. 1997. ISBN 0-7923-9900-5.

Verweij, J., Pinedo, H.M., Suit, H.D. (eds.): Soft Tissue Sarcomas: Present Achievements and Future Prospects. 1997. ISBN 0-7923-9913-7.

Walterhouse, D.O., Cohn, S. L. (eds.): Diagnostic and Therapeutic Advances in Pediatric Oncology. 1997. ISBN 0-7923-9978-1.

Mittal, B.B., Purdy, J.A., Ang, K.K. (eds.): Radiation Therapy. 1998. ISBN 0-7923-9981-1.

Foon, K.A., Muss, H.B. (eds.): Biological and Hormonal Therapies of Cancer. 1998. ISBN 0-7923-9997-8.

Ozols, R.F. (ed.): Gynecologic Oncology. 1998. ISBN 0-7923-8070-3.

Noskin, G. A. (ed.): Management of Infectious Complications in Cancer Patients. 1998. ISBN 0-7923-8150-5

Bennett, C. L. (ed.): Cancer Policy. 1998. ISBN 0-7923-8203-X

Benson, A. B. (ed.): Gastrointestinal Oncology. 1998. ISBN 0-7923-8205-6

Tallman, M.S. , Gordon, L.I. (eds.): Diagnostic and Therapeutic Advances in Hematologic Malignancies. 1998. ISBN 0-7923-8206-4

von Gunten, C.F. (ed.): Palliative Care and Rehabilitation of Cancer Patients. 1999. ISBN 0-7923-8525-X

Burt, R.K., M.M. Brush (eds): Advances in Allogeneic Hematopoietic Stem Cell Transplantation. 1999. ISBN 0-7923-7714-1

Angelos, P. (ed): Ethical Issues in Cancer Patient Care 2000. ISBN 0-7923-7726-5. 


\section{Ethical Issues in Cancer Patient Care}

Edited by

Peter Angelos, M.D., Ph.D.

Assistant Professor of Surgery

Assistant Professor of Medical Ethics and Humanities

Robert H. Lurie Comprehensive Cancer Center

Northwestern University Medical School Chicago, Illinois

1999 Springer Science+Business Media, LLC 
Library of Congress Cataloging-in-Publication Data

ISBN 978-1-4757-3046-3

ISBN 978-1-4757-3044-9 (eBook)

DOI 10.1007/978-1-4757-3044-9

99-049245

CIP

Copyright $\mathbb{C} 2000$ Springer Science+Business Media New York

Originally published by Kluwer Academic Publishers in 2000

Softcover reprint of the hardcover 1st edition 2000

All rights reserved. No part of this publication may be reproduced, stored in a retrieval system or transmitted in any form or by any means, mechanical, photocopying, recording, or otherwise, without the prior written permission of the publisher, Springer Science+Business Media, LLC.

Printed on acid-free paper. 
For Meghan, Christian, Audrey, and especially Grace. 


\section{CONTENTS}

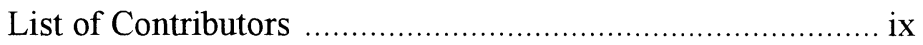

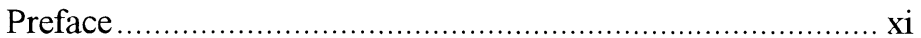

1. Physicians and Cancer Patients:

Communication and Advance Directives

Peter Angelos, M.D., Ph.D

2. Information is not Enough: The Place of Statistics in the Doctor-Patient

Relationship

Kathryn Montgomery, Ph.D

3. Cross-Cultural Issues in Caring for

Patients with Cancer

Tod Chambers, Ph.D.

4. Religious/Spiritual Concerns in Caring

For the Cancer Patient

James F. Bresnahan, S.J., J.D., L.L.M., Ph.D. and

John M. Merrill, M.D.

5. Are there Limits to Oncology Care?

(Futility)

Gary R. Shapiro, M.D.

6. Role of Palliative Medicine in Cancer

Patient Care

Charles F. von Gunten, M.D., Ph.D. and

Jeanne Martinez, R.N., M.P.H.

7. Informed Consent, The Cancer Patient, And Phase I Clinical Trials

Christopher K. Daugherty, M.D.

8. The Ethical Lessons of Managed Care Applied to Clinical Trials

Samuel Hellman, M.D. 
9. Kids and Cancer: Ethical Issues in

Treating the Pediatric Oncology Patient

Sarah E. Friebert, M.D. and

Eric D. Kodish, M.D.

10. Does Reimbursement Affect Physician

Decision Making?

Charles L. Bennett, M.D., Ph.D. and

Tammy J. Stinson, M.S.

Index 


\section{List of Contributors}

Peter Angelos, M.D., Ph.D. Assistant Professor of Surgery; Assistant Professor of Medical Ethics and Humanities, Robert H. Lurie Comprehensive Cancer Center, Northwestern University Medical School, 300 E. Superior Street, Tarry 11-703, Chicago, IL 60611

Charles Bennett, M.D., Ph.D. Director HSR \& D (Health Services Research \& Development), VA Chicago Health Systems, Lakeside, Associate Professor Medicine, Robert H. Lurie Comprehensive Cancer Center of Northwestern University, 400 E. Ontario, Suite 204, Chicago, IL 60611.

James Bresnahan, S.J., J.D., L.L.M. , Ph.D. Professor, Emeritus of Medical Ethics and Humanities and of Medicine, Northwestern Unversity, Ward Bldg. 3-130, CH W 117, 303 E. Chicago Avenue, Chicago, IL 60611

Tod Chambers, Ph.D. Assistant Professor of Medical Ethics and Humanities and of Medicine, Northwestern University, Ward Bldg. 3$130 \mathrm{CH}$ W 117, 303 E. Chicago Avenue, Chicago, IL 60611.

Christopher Daugherty, M.D. Assistant Professor of Medicine, Section of Hematology/Oncology, Department of Medicine, Associate Faculty Center for Clinical Medical Ethics, University of Chicago, Vice-Chair of Institutional Review Board, University of Chicago, 5841 S. Maryland, MC-2115, Chicago, IL 60637-1470.

Sarah E. Friebert, M.D. Associate Professor of Pediatrics, Pediatric Hematology/Oncologist, St. Vincent Mercy Medical/Mercy Children's Hospital, Associate Medical Director and Pediatric Director at Hospice of Western Reserve, Case Western Reserve, 300 E. $185^{\text {th }}$ Street, Cleveland, OH 44119

Samuel Hellman, M.D. A.N. Pritzker Distinguished Services Professor, Department of Radiation of Cellular Oncology. University of Chicago, 5758 S. Maryland, D CAM Rm 1339, MC 9001, Chicago, IL 60637-1470. 
Eric Kodish, M.D. Associate Professor of Pediatrics, Oncology, and Biomedical Ethics. Case Western Reserve, Rainbow, Babies and Children's Hospital, Room 310, 11100 Euclid Avenue, Cleveland, $\mathrm{OH}$ 44106 .

Jeanne Martinez, R.N., M.P.H., CRNH Coordinator of Center for Palliative Medicine, Education and Research, 400 E. Ontario, Suite 204, Chicago, IL 60611

John M. Merrill, M.D. Associate Professor, Clinical/Medicine Hematology/Oncology. Robert H. Lurie Comprehensive Cancer Center, 676 N. St. Clair, Suite 2140, Chicago, IL 60611-2998

Kathryn Montgomery, Ph.D. Professor of Medical Ethics and Humanities and of Medicine, Program Director, Northwestern Unversity, Ward Bldg. 3-130, CH W 117, 303 E. Chicago Avenue, Chicago, IL 60611

Gary Shapiro, M.D. Associate Professor of Medicine, Head, Medical Oncology Division, Milwaukee, University of Wisconsin Medical School, Sinai Samaritan Medical Center, 945 N. $12^{\text {th }}$ Street, P.O. Box 342, Milwaukee, WI 53201

Charles von Gunten, M.D., Ph.D. Medical Director, Center for Palliative Studies, 4311 Third Avenue, San Diego, CA 92103-1407. 


\section{Preface}

This book addresses a variety of ethical issues that arise in the care of oncology patients. Many volumes have been written on medical ethics in the past 30 years. However, few have focused on ethical issues specific to the care of cancer patients. This book brings together such a focused examination.

The contributors are experienced clinicians, ethicists, medical humanists, and medical educators. The issues raised have direct relevance to the care of oncology patients in treatment as well as research settings.

The chapters address issues that are central to contemporary medical practice and medical ethics inquiry. Any practicing clinician will be well aware of the problems of communication and how uncertainty, cross-cultural issues, and religious influences can impact patient care. The limits of care and the role of advance directives and palliative care are common issues that must be addressed in treating patients at the end of life. For oncologists and oncology patients, participation in clinical trials may be a thoray topic, especially when phase I clinical trials are being considered. The impact of managed care and reimbursement issues cannot be avoided in the contemporary patient care and similarly cannot be neglected when considering the ethical ramifications raised. No discussion of ethics in oncology can be complete without attention to the specific challenges raised by the pediatric patient with cancer. All of these topics are explored by the contributors to this book.

This volume will have direct importance for practicing physicians, nurses, and other care- givers who take care of cancer patients. In addition, medical students, medical educators, and ethicists should find this book of interest as well.

A book such as this is the result of the efforts of many people. I am appreciative of the hard work of all of the contributors. I would like to thank Steven Rosen, M.D., the series editor of Cancer Treatment and Research, for his insights in realizing the importance of a volume on medical ethics in the series. Melissa Ramondetta and her staff at Kluwer have been helpful and patient over the previous months. Sandra Kuipers has helped in numerous ways. Special thanks are owed to Alex Langerman for his invaluable assistance in the final manuscript preparation of this book. Of course, I would never have been able to complete a project such as this without the patience and support of my family. Thank you all. 